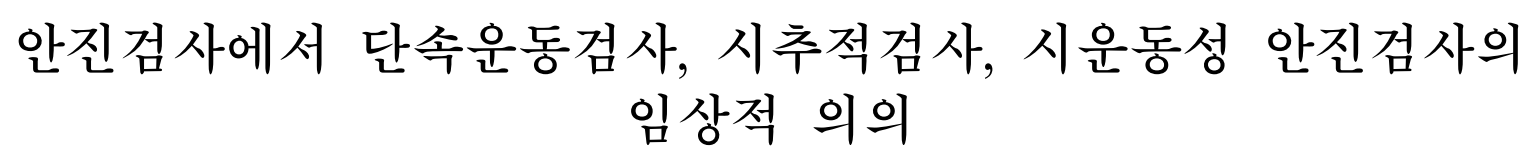

\author{
최윤석 ${ }^{1}$, 나형균 $^{1}$, 송시연 ${ }^{1}$, 김용대 ${ }^{1,2}$, 배창훈 $^{1}$ \\ ${ }^{1}$ 영남대학교 의과대학 이비인후-두경부외과학교실, ${ }^{2}$ 영남대학교병원 권역 호흡기 전문질환센터
}

\title{
Clinical significance of saccade test, smooth pursuit test, and optokinetic nystagmus test in nystagmography
}

\author{
Yoon Seok Choi ${ }^{1}$, Hyung Gyun $\mathrm{Na}^{1}$, Si-Youn Song ${ }^{1}$, Yong-Dae Kim ${ }^{1,2}$, Chang Hoon Bae ${ }^{1}$ \\ ${ }^{I}$ Department of Otorhinolaryngology-Head and Neck Surgery, Yeungnam University College of Medicine; \\ ${ }^{2}$ Regional Center for Respiratory Diseases, Yeungnam University Medical Center, Daegu, Korea
}

Background: Saccade test, smooth pursuit test, and optokinetic nystagmus test are clinically useful tests to accurately diagnose vertigo. However, there have only been a few studies regarding a correlation between the anatomical site of the lesion and the abnormality of eyeball movement in patients with vertigo.

Methods: The medical records of 97 patients with vertigo between January 2006 and June 2008 were reviewed retrospectively. We classified many kinds of abnormalities regarding the saccade test, smooth pursuit test and optokinetic nystagmus test into several categories and analyzed the localizing lesion of vertigo. Results: According to the saccade test, both total saccade abnormality (S-total) and slow velocity of saccade (S-type 3) were shown to be significantly higher in the central lesion of vertigo. According to the smooth pursuit test, symmetrical unidirectional smooth pursuit abnormality (SP-type 2) was observed to be significantly higher in the peripheral lesion over vertigo. Moreover, according to the optokinetic nystagmus test, total optokinetic nystagmus abnormalities (OKN-total) were shown to be significantly useful findings in the diagnosis of the central lesion of vertigo. The coexisting abnormalities of all three tests $(\mathrm{S}+\mathrm{SP}+\mathrm{OKN}$ abnormalities) were shown to be significantly higher in the central lesion of vertigo.

Conclusion: These results suggest that all these tests, saccade test, smooth pursuit test, and optokinetic nystagmus test, are very useful to distinguish between the central lesion and the peripheral lesion of vertigo. However, these tests are not beneficial in localizing the central lesion of vertigo.

Keywords: Vertigo; Saccade test; Smooth pursuit test; Optokinetic nystagmus test

Received: November 4, 2016, Revised: April 28, 2017 Accepted: May 4, 2017

Corresponding Author: Chang Hoon Bae, Department of Otorhinolaryngology-Head and Neck Surgery, Yeungnam University College of Medicine, 170, Hyeonchung-ro,

Nam-gu, Daegu 42415, Korea

Tel: +82-53-620-3785, Fax: +82-53-628-7884

E-mail: baich@med.yu.ac.kr

\section{서 론}

안진검사는 전정계와 시각계가 서로의 정보를 종합하여 발현되는 안구운동을 평가하는 검사로서, 어지럼증 환자에 서 중추성 어지럼증과 말초성 어지럼증을 감별진단하는데 중요한 목적을 두고 있다. 안진검사 중 단속운동검사(saccade test)와 시추적검사(smooth pursuit test), 시운동성 안진검사

Copyright $(52017$ Yeungnam University College of Medicine

This is an Open Access article distributed under the terms of the Creative Commons Attribution Non-Commercial License (http://creativecommons.org/licenses/by-nc/4.0/) which permits unrestricted non-commercial use, distribution, and reproduction in any medium, provided the original work is properly cited. 
(optokinetic nystagmus test)에서 이상소견을 보일 경우에는 반드시 중추성 어지럼증의 유무를 확인해야 한다. 단속안구 운동은 새로이 나타난 물체에 시야를 고정시키려는 빠른 안 구운동으로, 안구를 새로운 위치로 이동시키는 위상성 신경 지배(pulse innervation)와 이동된 안구의 위치를 유지하는 긴장성 신경지배를 받고 있다[1,2]. 시추적안구운동은 느리 게 움직이는 작은 물체를 따라 봄으로써 물체를 망막오목 (retina fovea)에 정확하게 맺히도록 계속 추적하게 하는 반사 운동으로, 두부가 움직일 때도 물체의 상을 망막오목에 고정 시킬 수 있도록 도와준다[3]. 시운동성 안진은 전정계와 추적 계를 보완하여 40 도초 이상의 속도로 움직이는 물체를 계속 주시할 때 불수의적으로 일어나는 정상적인 안구운동이다 [4]. 이들 안구운동들은 다양한 중추신경계의 작용으로 발생 하며 중추신경계에 병변이 있을 때 다양한 형태의 이상소견 을 보이게 된다. 현재까지 단속운동검사와 시추적검사, 시운 동성 안진검사의 임상적 의의와 해부신경학적 구조에 대한 연구는 많이 이루어졌으나, 검사간의 복합적 이상에 대한 임상적 의미에 관한 연구는 많이 보고되지 않았다. 이에 본 연구에서는 이들 세가지 검사의 이상소견을 분류하고 검사 결과의 비교분석을 통해 중추성 어지럼증의 감별과 병변 위 치의 예상에 어느 정도의 진단적 유용성과 임상적 의미를 가지는지를 알아보고자 하였다.

\section{재료 및 방법}

\section{1. 대상}

2006년 1월부터 2008년 6월까지 어지럼증 증상으로 영남 대학교병원 이비인후과를 내원하여 안진검사를 시행한 환자 는 245 명이었다. 그 중 자발안진이 없었던 환자는 211 명이었 고, 단속운동검사와 시추적검사, 시운동성 안진검사에서 한 가지 이상 검사에서 비정상소견을 보인 환자는 125 명이였 다. 본 연구는 125 명의 환자 중 진단 기준에 근거하여 명확하 게 말초성 어지럼증인 전정신경염(vestibular neuronitis), 메 니에르병(Meniere's disease), 양성발작성 체위성 현훈(benign paroxysmal positional vertigo)으로 진단이 가능했던 환자와 뇌 자기공명검사에서 명확한 중추성 병변의 국재화(localization)가 가능했던 허혈성, 외상성, 퇴행성, 감염성 뇌질환 환 자 97명을 대상으로 후향적으로 의무기록 분석을 통해 시행 하였다. 명확한 진단과 병변의 국재화를 위해서 철저한 병력 검사, 순음청력검사, 이신경학적검사 및 전기안진검사를 포
함한 평형기능 검사를 시행하였으며, 중추성 병변의 유무를 확인하기 위하여 뇌 자기공명검사를 시행하였다. 뇌 자기공 명검사를 시행하지 않아 말초 및 중추성 어지럼증의 동반 가능성을 확인할 수 없는 환자는 본 연구에서 제외되었으며, 중추성 어지럼증으로 진단된 환자 중 다발성 병변을 가지고 있어 병변의 위치와 안진검사간의 연관성에 대한 분석이 어 려운 환자, 각 질환별 진단 기준을 충분히 만족시키지 않아 명확한 진단이 어려웠던 어지럼증 환자 또한 제외되었다. 진단과정에서 안과질환, 전신질환, 편두통성 어지럼증 등으 로 최종 진단된 환자 또한 본 연구에서 제외되었다. 본 연구 는 본원 임상연구윤리위원회(Institutional Review Board)의 승인(YUMC 2016-09-014)을 받아 시행하였다.

\section{2. 검사방법}

진단과 병변의 국재화를 위해 병력청취와 안진검사, 뇌 자기공명영상검사(Philips MRI system 1.5T INTERA, Siemens symphony vision $1.5 \mathrm{~T}$ )를 시행하였다. 안진검사는 암실 에서 비디오안진검사기(Interacoustic company, VNG system $\mathrm{VN15/VO25)를} \mathrm{이용하여} \mathrm{개안상태로} \mathrm{하였으며,} \mathrm{단속운동검}$ 사와 시추적검사, 시운동성 안진검사를 시행하였다.

\section{1) 단속운동검사}

자발안진을 1 분간 측정한 후 시자극 목표를 중심으로 6 도부터 32도의 범위에서 무작위 단속운동(random saccade movement) 자극을 주어 단속운동검사를 시행하였다. 단속운 동검사 결과의 진폭이상은 진폭의 $10 \%$ 이상 안구운동 차이 가 있는 경우로 저겨냥이상(undershoot; S-type 1)과 과겨냥 이상(overshoot; S-type 2)으로 분류하였고, 단속운동 속도장 애(slow velocity of saccade; S-type 3)는 정상인의 단속운동의 표준치(20세 미만: 좌측 $162.4 \pm 86.8 \mathrm{msec}$, 우측 $169.4 \pm 85.4$ $\mathrm{msec}, 20-39$ 세: 좌측 $170.8 \pm 43.8 \mathrm{msec}$, 우측 $176.5 \pm 58.0$ $\mathrm{msec}, 40-59$ 세: 좌측 $192.9 \pm 70.0 \mathrm{msec}$, 우측 $184.6 \pm 53.2$ $\mathrm{msec}, 60$ 세 이상: 좌측 $200 \pm 73.4 \mathrm{msec}$, 우측 $206.5 \pm 67.2$ $\mathrm{msec}$ 와 비교해서 표준편차 2배 이상 안구운동 차이가 있는 경우로 정의하였다[5]. 단속운동 불규칙(impaired saccade; S-type 4)은 단속운동에 대한 반응은 보이나 반응이 규칙적이 지 않으며, 진폭이나 반응속도 또는 두 가지 모두가 정상인에 비해 감소된 경우로 정의하였다. 또한 단속운동 불능(fail of saccade; S-type 5)은 시야자극에 안구가 전혀 반응하지 못하 는 경우로 정의하여, 총 5 가지로 분류하여 조사하였다[6]. 


\section{2) 시추적검사}

단속운동검사 종료 후 5 분의 간격을 두고 시자극 목표물 을 주파수 $0.5 \mathrm{~Hz}$, 진폭 10 도, 각 속도 40 도/초로 설정하여 30 초간 시운동 자극을 주어 시행하였다. 양안 모두에서 양방 향 시추적 검사 이상파형을 보이는 경우(symmetrical bidirectional smooth pursuit impairment; SP-type 1), 양안 모두 한 방향에서만 이상파형을 보이는 경우(symmetrical unidirectional smooth pursuit impairment; SP-type 2), 양안이 서로 다른 형태의 파형을 보이는 경우(asymmetrical smooth impairment; SP-type 3)의 세가지로 분류하여 조사하였다.

\section{3) 시운동성 안진검사}

시추적검사 완료 후 5 분 후에 시행하였고, 시야자극을 각 속도 45도/초와 목표 간의 간격을 5.12도로 설정하고 시행하 였다. 시운동성 안진의 방향이 좌우 모두 정상이고, 평균 완서 상 안구운동의 양측 차이가 10 도 이상인 경우(the direction of optokinetic response is normal, but right and left meanvelocity is greater than 10 degree/sec; OKN-type 1), 시운동 성 안진의 방향이 좌측이나 우측방향의 시운동성 안진 중에 한쪽만이 정상 안구운동에 비하여 방향이 반대로 나타나는 경우(only one direction of optokinetic response is reversed; $\mathrm{OKN}$-type 2), 시운동성 안진의 방향이 좌우 모두 정상 시운 동 안진에 비하여 방향이 역전되어 나타나는 경우(the directions of the both optokinetic response are reversed; OKN-type 3)의 세가지로 분류하여 조사하였다[4].

\section{3. 통계분석}

검사 결과의 비교를 위하여 Pearson Chi-square test (SPSS V11.5, SPSS Inc., Chicago, IL, USA)를 이용하였으며, $p<0.05$ 일때 통계학적 유의성이 있는 것으로 판정하였다.

\section{결 과}

전체 대상 환자 97명 중 남자가 44명(45.4\%), 여자가 53명 (54.6\%)으로 여자가 다소 많았으며, 연령 분포는 13-78세로 평균 55.1세였다. 중추성 어지럼증이 56명(57.7\%), 말초성 어지럼증이 41명(42.3\%)이었다. 중추성 어지럼증의 병변부 위는 대뇌(cerebrum) 24명(24.7\%)과 소뇌(cerebellum) 6명 (6.2\%), 기저핵(basal ganglia) 6명(6.2\%), 시상부(thalamus) 3명(3.1\%), 뇌간(brainstem) 4명(4.1\%), 척골기저동맥 순환부 전(vertebrobasillar insufficiency) 13명(13.4\%)이었다(Table 1).
말초성 어지럼증의 원인은 전정신경염 20명(20.6\%), 메니에 르병 13명(13.4\%), 양성발작성 체위성 현훈 8명(8.2\%)이었 다. 전체적으로 중추성 어지럼증의 원인으로는 대뇌 병변이 가장 많았고, 말초성 어지럼증의 원인으로는 전정신경염이 가장 많았다(Table 1). 안진검사의 이상소견은 단속운동검사 에서 34명(35.1\%)과 시추적검사에서 83명(85.6\%), 시운동 성 안진검사에서 29명(29.9\%)으로 관찰되어 시추적검사에 서 이상소견이 가장 많았다.

\section{1. 단속운동검사}

단속운동검사는 97 명의 환자 중 이상소견을 보인 34명 (35.1\%)에서 25명(25.8\%)이 중추성 어지럼증으로, 9명(9.3\%) 이 말초성 어지럼증으로 진단되었다. 이상파형 형태별로 살 펴보면, S-type 1은 3명(3.1\%)이 말초성 어지럼증에서 관찰 되었으나 중추성 어지럼증은 없었다. S-type 2와 S-type 3, S-type 4는 중추성 및 말초성 어지럼증에서 모두 나타났으나, 중추성 어지럼증에서 다소 높게 관찰되었다. S-type 5 의 경우 는 중추성 어지럼증 중 대뇌 병변환자 1 명(1.0\%)과 척골기저 동맥 순환부전 환자 1 명(1.0\%)에서 관찰되었으며, 말초성 어지럼증에서는 나타나지 않았다(Table 2).

단속운동검사의 이상소견과 이상파형 각각에 따른 중추성 어지럼증과 말초성 어지럼증의 연관성에 관한 조사에서는

Table 1. Patients demographics

\begin{tabular}{lc}
\hline Characteristics & Number of patients (\%) \\
\hline Total & $97(100)$ \\
Sex & \\
Male & $44(45.4)$ \\
Female & $53(54.6)$ \\
Diagnosis & \\
Central vertigo (n=56) & $56(57.7)$ \\
Cerebral lesion & $24(24.7)$ \\
Cerebellar lesion & $6(6.2)$ \\
Basal ganglia lesion & $6(6.2)$ \\
Thalamic lesion & $3(3.1)$ \\
Brainstem lesion & $4(4.1)$ \\
VBI & $13(13.4)$ \\
Peripheral vertigo $(n=41)$ & $41(42.3)$ \\
VN & $20(20.6)$ \\
Meniere's disease & $13(13.4)$ \\
BPPV & $8(8.2)$
\end{tabular}

VBI, vertebrobasillar insufficiency; VN, vestibular neuronitis; BPPV, benign paroxysmal positional vertigo. 
전체적인 단속운동검사 이상소견(S-total)이 중추성 어지럼 증에서 의미 있게 높은 것으로 나타났으며, S-type 3도 중추 성 어지럼증에서 통계학적으로 의미 있게 높은 것으로 나타 났다. 반면, S-type 1은 말초성 어지럼증에서 높게 나타났으 나 통계학적인 유의성은 없었고, S-type 2 와 4, 5 는 모두 어지 럼증의 원인질환과의 통계학적 유의성은 없었다(Table 2). 또한 해부학적 병변부위와 단속운동검사 이상소견 형태와의 연관성은 통계학적으로 유의하지 않았다.

\section{2. 시추적검사}

시추적검사는 97 명의 환자 중 83 명(85.6\%)에서 이상소견 을 보여 세가지 검사 중 가장 높은 이상소견 빈도를 나타냈으 며, 중추성 어지럼증이 47 명 $(48.5 \%)$ 이었고, 말초성 어지럼증 이 36명(37.1\%)이었다. 이상파형 형태별로 살펴보면, SP-type 1 은 55명(56.7\%)에서 관찰되었다. 이 중 중추성 질환은 31 명 (32.0\%)으로 대뇌 병변이 12 명(12.4\%)으로 가장 많았고, 말

Table 2. The relationship between the types of saccade abnormalities and lesional causes of vertigo

\begin{tabular}{lcccccc}
\hline & Total & Type 1 & Type 2 & Type 3 & Type 4 & Type 5 \\
\hline Central lesion (n=56) & & & & & & \\
$\quad$ Cerebral lesion & 10 & 0 & 2 & 3 & 4 & 1 \\
Cerebellar lesion & 1 & 0 & 0 & 0 & 1 & 0 \\
Basal ganglia lesion & 2 & 0 & 2 & 0 & 0 & 0 \\
Thalamic lesion & 2 & 0 & 2 & 0 & 0 & 0 \\
Brainstem lesion & 3 & 0 & 1 & 2 & 0 & 0 \\
VBI & 7 & 0 & 1 & 3 & 2 & 1 \\
Subtotal & $25^{\text {a) }}$ & 0 & 8 & $8^{\text {a) }}$ & 7 & 2 \\
Peripheral lesion (n=41) & 5 & 3 & 1 & 1 & 0 & 0 \\
VN & 2 & 0 & 1 & 0 & 1 & 0 \\
Meniere's disease & 2 & 0 & 1 & 0 & 1 & 0 \\
BPPV & 9 & 3 & 3 & 1 & 2 & 0 \\
Subtotal & 34 & 3 & 11 & 9 & 9 & 2 \\
Total & & & & & \\
\hline
\end{tabular}

VBI, vertebrobasillar insufficiency; VN, vestibular neuronitis; BPPV, benign paroxysmal positional vertigo.

a) $p<0.05$.

Table 3. The relationship between the types of smooth pursuit abnormalities and the lesional causes of vertigo

\begin{tabular}{|c|c|c|c|c|}
\hline & Total & Type 1 & Type 2 & Type 3 \\
\hline \multicolumn{5}{|l|}{ Central lesion $(\mathrm{n}=56)$} \\
\hline Cerebral lesion & 22 & 12 & 1 & 9 \\
\hline Cerebellar lesion & 4 & 3 & 0 & 1 \\
\hline Basal ganglia lesion & 6 & 4 & 1 & 1 \\
\hline Thalamic lesion & 3 & 3 & 0 & 0 \\
\hline Brainstem lesion & 3 & 1 & 0 & 2 \\
\hline VBI & 9 & 8 & 0 & 1 \\
\hline Subtotal & 47 & 31 & 2 & 14 \\
\hline \multicolumn{5}{|l|}{ Peripheral lesion $(n=41)$} \\
\hline $\mathrm{VN}$ & 18 & 11 & 6 & 1 \\
\hline Meniere's disease & 11 & 8 & 2 & 1 \\
\hline BPPV & 7 & 5 & 2 & 0 \\
\hline Subtotal & 36 & 24 & $10^{\mathrm{a})}$ & 2 \\
\hline Total & 83 & 55 & 12 & 16 \\
\hline
\end{tabular}

VBI, vertebrobasillar insufficiency; VN, vestibular neuronitis; BPPV, benign paroxysmal positional vertigo. a) $p<0.05$. 
초성 질환는 24명(24.7\%)으로 전정신경염이 11명(11.3\%) 으로 가장 많았다. SP-type 2는 12 명(12.4\%)으로 중추성 어 지럼증에서 2명(2.1\%)과 말초성 어지럼증에서 10명(10.3\%) 이 나타났으며, 말초성 어지럼증에서 가장 높은 빈도를 보였 다. SP-type 3는 16명(16.5\%)으로 중추성 어지럼증에서 14 명(14.4\%)과 말초성 어지럼증에서 2명(2.1\%) 나타났으며, 중추성 어지럼증에서 가장 높은 빈도를 보였다(Table 3).

시추적검사의 이상소견과 이상파형 각각에 따른 중추성 어지럼증과 말초성 어지럼증의 연관성에 관한 조사에서는 전체 시추적검사이상(SP-total)과 SP-type 1, SP-type 3에서 어지럼증 원인질환과의 통계학적 연관관계는 없었으나, SPtype 2 이상소견만 말초성 어지럼증에서 통계학적으로 높게 나타났다(Table 3). 그러나 해부학적 병변부위와 시추적검사 이상소견 형태와의 연관성은 통계학적으로 유의하지 않았다.

\section{3. 시운동성 안진검사}

시운동성 안진검사 이상은 97 명의 환자 중 29명(29.9\%)에 서 나타났으며, 세가지 검사 중 가장 낮은 이상소견 빈도를 나타냈다. 이 중 22명(22.7\%)이 중추성 어지럼증으로, 7 명 (7.2\%)이 말초성 어지럼증으로 진단되었다. 이상파형 형태 별로 살펴보면, OKN-type 1은 26명(26.8\%)으로 중추성 어 지럼증은 19명(19.6\%)과 말초성 어지럼증은 7명(7.2\%)으로 나타났다. OKN-type 2는 3명(3.1\%)에서 나타났으며 모두가 중추성 어지럼증으로 진단되었고, OKN-type 3 소견이 나타
나는 질환은 없었다(Table 4).

시운동성 안진검사 이상소견과 이상파형 각각에 따른 중 추성 어지럼증과 말초성 어지럼증의 연관성에 관한 조사에 서는 시운동성 안진검사 이상이 중추성 어지럼증에서 통계 학적으로 높게 나타났으나, 이상파형 형태와 어지럼증 원인 질환과의 관계와 해부학적 병변부위와의 연관성은 통계학적 으로 유의하지 않았다(Table 4).

\section{4. 안진검사간의 비교분석}

단속운동검사 이상과 시추적검사 이상, 시운동성 안진검 사 이상소견들간의 비교를 통한 병변 위치와의 연관성은 단 속운동검사 이상과 시추적검사 이상이 함께 나타난 경우가 21명(21.6\%)으로 가장 많았고, 중추성 어지럼증이 13명 (13.4\%), 말초성 어지럼증이 8명(8.2\%)이었다.

단속운동검사 이상과 시운동성 안진검사 이상이 함께 나 타난 경우는 2명(2.1\%)으로 가장 빈도가 낮았으며, 2명 모두 중추성 어지럼증 중 대뇌 병변이 있었다. 시추적운동 이상과 시운동성 안진검사 이상이 함께 나타난 환자는 12 명(12.4\%) 으로, 중추성 어지럼증이 9명(9.3\%), 말초성 어지럼증이 3명 (3.1\%)이었다. 세가지 검사 모두에서 이상을 보인 어지럼증 은 9명(9.3\%)으로 8 명(8.3\%)이 중추성 어지럼증, 1 명(1.0\%) 이 말초성 어지럼증으로 진단되었으며, 중추성 어지럼증 중 에서는 척골기저동맥 순환부전이 5 명(5.2\%)으로 가장 많았 다. 이 분석에서는 말초성 어지럼증의 진단에 통계학적인

Table 4. The relationship between the types of optokinetic nystagmus abnormalities and the lesional causes of vertigo

\begin{tabular}{lcccc}
\hline & Total & Type 1 & Type 2 & Type 3 \\
\hline Central lesion (n=56) & & & & \\
Cerebral lesion & 9 & 8 & 1 & 0 \\
Cerebellar lesion & 3 & 3 & 0 & 0 \\
Basal ganglia lesion & 1 & 1 & 0 & 0 \\
Thalamic lesion & 1 & 1 & 0 & 0 \\
Brainstem lesion & 2 & 1 & 1 & 0 \\
VBI & 6 & 5 & 1 & 0 \\
Subtotal & $22^{\text {a) }}$ & 19 & 3 & 0 \\
Peripheral lesion (n=41) & & & 0 & 0 \\
VN & 4 & 4 & 0 & 0 \\
Meniere's disease & 2 & 2 & 0 & 0 \\
BPPV & 1 & 1 & 0 & 0 \\
Subtotal & 7 & 7 & 3 & \\
Total & 29 & 26 & 0 \\
\hline VB
\end{tabular}

VBI, vertebrobasillar insufficiency; VN, vestibular neuronitis; BPPV, benign paroxysmal positional vertigo. a) $p<0.05$. 
Yoon Seok Choi et al.

Table 5. The relationship between the abnormalities of saccade, smooth pursuit, optokinetic nystagmus and the lesional causes of vertigo

\begin{tabular}{|c|c|c|c|c|}
\hline & $\mathrm{S}+\mathrm{SP}$ & $\mathrm{S}+\mathrm{OKN}$ & $\mathrm{SP}+\mathrm{OKN}$ & $\mathrm{S}+\mathrm{SP}+\mathrm{OKN}$ \\
\hline \multicolumn{5}{|l|}{ Central lesion $(\mathrm{n}=56)$} \\
\hline Cerebral lesion & 6 & 2 & 5 & 1 \\
\hline Cerebellar lesion & 1 & 0 & 1 & 0 \\
\hline Basal ganglia lesion & 2 & 0 & 1 & 0 \\
\hline Thalamic lesion & 1 & 0 & 0 & 1 \\
\hline Brainstem lesion & 1 & 0 & 1 & 1 \\
\hline VBI & 2 & 0 & 1 & 5 \\
\hline Subtotal & 13 & 2 & 9 & $8^{\text {a) }}$ \\
\hline \multicolumn{5}{|l|}{ Peripheral lesion $(n=41)$} \\
\hline $\mathrm{VN}$ & 3 & 0 & 1 & 1 \\
\hline Meniere's disease & 2 & 0 & 2 & 0 \\
\hline BPPV & 3 & 0 & 0 & 0 \\
\hline Subtotal & 8 & 0 & 3 & 1 \\
\hline Total & 21 & 2 & 12 & 9 \\
\hline
\end{tabular}

S, positive of saccade abnormality; SP, positive of smooth pursuit abnormality; OKN, positive of optokinetic nystagmus abnormality; VBI, vertebrobasillar insufficiency; VN, vestibular neuronitis; BPPV, benign paroxysmal positional vertigo.

a) $p<0.05$.

유의성을 보인 S-type 1 이상소견과 SP-type 2 이상소견은 배제하였다(Table 5).

세가지 검사 이상소견 간의 각기 다른 조합과 원인 질환간 의 연관성에 관한 조사에서는 세가지 검사 모두에서 이상소견 을 보인 경우에서 중추성 어지럼증 진단에 통계학적으로 유의 한 것으로 나타났다. 그러나 다른 이상소견 간의 조합과 원인 질환간의 관계와 해부학적 병변부위와의 연관성은 통계학적 으로 유의하지 않았다(Table 5).

\section{고 찰}

머리를 움직일 때 시야를 안정화시키기 위한 작용으로 시 각계와 전정계의 정보가 서로 협조한다. 시야를 안정화하는 세가지 시각계는 단속안구운동과 시추적운동, 시운동성 안 구운동이다. 세가지 운동의 평가에 사용되는 안진검사는 중 추성 어지럼증과 말초성 어지럼증의 감별진단에 중요하게 사용되고 있다.

단속운동검사는 서로 다른 각도로 빠르게 수평방향으로 움직이는 목표물에 대한 안구운동을 관찰함으로써 목표물을 망막오목에 빠르고 정확하게 고정할 수 있는 안구운동 체계 의 능력을 측정하는 것이다[6,7]. 단속안구운동의 신경전달 은 안구운동시 발생하는 전기신호가 반대쪽 전두엽에서 기 시하여 다접속경로(multi-synaptic pathway)를 거쳐 뇌간의 중뇌(midbrain)에서 반대쪽으로 교차해서 전달되고, 이 전기
신호는 외전신경핵(abducens nucleus) 근처에서 모이게 되는 데, 이 부위가 정중방뇌교망상체(paramedian pontine reticular formation)이다. 이 부위에서 전기신호는 동측 외전신 경핵과 반대측 동안근 신경핵(oculomotor nucleus)으로 분포 하여 각각의 신경핵에서 외안근의 운동을 조절하여 단속 안구 운동이 나타난다[8]. 또한 소뇌의 충부(vermis)에 존재하는 퍼킨지 세포 축삭(Purkinje-cell axon)의 활성에 의해서도 단속 안구운동이 유발된다[9]. 그러므로 이러한 신경전달경로에 기능적 이상이 초래되면 단속운동 검사에서 안구운동의 속 도와 정확도, 잠복기, 안정도에 이상소견을 보인다[10]. 그러 나 말초신경계 질환환자 및 정상인에서도 교정성 단속운동 (corrective saccade)을 보이기도 하고, 고령, 진정제나 항히스 타민제 등의 약물복용에 등의 여러 가지 요인에 의해서도 단속운동의 이상소견이 나타난다[4,11,12]. 또한 어지러움 의 급성기에 있는 환자는 주의력 감소 및 자발안진의 존재여 부와 다른 뇌신경, 특히 안면신경의 마비 등이 동반되어 있는 경우, 시력이 저하되어 있는 경우에서도 단속운동 검사상 병변부위와 연관성 없이 비정상적인 소견을 보인다[6]. 이러 한 경우 단속운동계의 이상으로 나타나는 단속운동 장애인 지 아니면 검사 시행의 오차인지를 판별하기 어렵다. 그러므 로 단속운동 장애에 대한 검사해석에는 정상 교정성 단속운 동과 피검자의 집중력저하, 검사자의 경험 미숙, 안과적 질환 의 유무 등을 면밀히 확인한 후 판독해야 한다[3,6]. 본 연구 에서는 전체적으로 단속운동검사 이상소견이 중추성 어지럼 
증에서 의미 있게 높게 나타나므로, 어지럼증 환자에서 단속 운동검사 이상소견이 나타날 경우에는 중추성 어지럼증을 먼저 고려하여야 한다.

시추적검사는 저주파, 저속도로 움직이는 물체를 망막오 목에 정확하게 맺히도록 계속 추적하는 안구의 움직임을 보 는 검사이다. 시추적운동의 신경전달 경로는 감각경로와 운 동경로의 2가지로 구분되는데, 감각경로는 망막(retina) - 시 신경(optic nerve) - 외측무릎체(lateral geniculate body) - 후 두엽(occipital lobe)으로 구성되며, 운동경로는 후두엽 - 측두 엽의 시각영역(temporal visual area) - 두정엽의 후부(posterior parietal lobe) - 외후뇌교핵(dorsal lateral pontine nucleus) 소뇌 - 뇌간의 전정핵(vestibular nucleus) - 뇌간의 동안근 신경 핵으로 이루어져, 이 경로를 포함한 병변이 존재할 경우 비정 상적인 시추적운동 이상이 나타난다[13]. 시추적검사 이상 소견은 급성 중추성 어지럼증에서 이상소견을 보이는 경우 가 많으며, 시운동성 안진검사와 달리 급성기 후 1-2주가 지 나도 남아 있는 경우가 많아 중추성 어지럼증을 진단하는데 용이하다[14]. 그러나 이 검사 역시 말초신경 질환환자에서 자발안진이 심할 경우와 약물복용, 각성의 저하 등의 요소에 의해서도 다양한 형태의 시추적검사의 이상소견이 나타난다 $[15,16]$. 본 연구에서는 시추적검사 이상소견 중 양안 모두 한 방향에서만 이상파형을 보이는 경우인 SP-type 2가 말초 성 어지럼증에서 통계학적으로 의미 있게 높게 나타나므로, 어지럼증 환자에서 SP-type 2 이상소견이 나타날 경우에는 말초성 어지럼증을 먼저 고려하여야 한다.

시운동성 안진검사는 40도/초 이상의 속도로 빠르게 움직 이는 물체를 추적하는 안구의 움직임을 측정하는 검사로 신 경전달 경로는 보조 시각계(accessory optic tract)와 시신경핵 (optic nucleus)의 핵내에서 이루어진다. 시운동자극이 동안 근에 도달하는 경로는 편엽(flocculus)과 전정핵을 통하여 전 달되고, 뇌교 망상체에서 통합되어 동안근 신경에 전달된다 $[4,17]$. 이와 같이 시각을 안정화시키는 복잡한 신경전달체 계로 인해 병의 종류나 검사 시기, 또는 환자의 상태에 따라 다양한 양상의 검사 이상을 보인다. 그 중에서도 연령적인 요인을 가장 주의하여야 한다. 정상인에서도 시운동성 안진 의 완서상 안구속도가 연령에 따라 점차적으로 줄어들기 때 문이다[3,18]. 이외에도 말초성 어지럼증, 선천성 안진, 선천 성 사시, 외안근 마비 같은 안구질환 환자에서도 시운동성 안진검사의 이상소견이 나타난다[4,19]. 본 연구에서는 시운 동성 안진검사 이상소견은 파형에 관계없이 중추성 어지럼 증에서 통계학적으로 의미 있게 나타나므로, 어지럼증 환자
에서 시운동성 안진검사 이상소견이 나타날 경우에는 중추 성 어지럼증을 먼저 고려하여야 한다.

어지럼증의 원인을 발견하기 위한 검사로 안진검사에 대 한 여러 연구들이 시행되었으나, 아직까지 안진검사의 이상 소견과 병변의 해부학적인 위치와의 상관관계는 명확하게 밝혀져 있지 않다. 본 연구에서도 다양한 형태로 단속운동검 사 이상, 시추적검사 이상, 시운동성 안진검사 이상소견을 분류한 후 통계학적으로 분석해 보았지만, 중추성 어지럼증 의 병변 위치와의 연관성은 없었다. 이는 본 연구에서 사용된 안진검사의 이상소견에 대한 분류가 여러 형태의 이상소견 을 분석하기에는 분류 범위가 너무 단순화된 것으로 생각되 며, 파형 모양에 중점을 두어 안구운동 속도와 정확도, 잠복 기, 안정도 등을 고려하여 좀 더 다변화된 검사 이상소견의 분류를 통한 해부학적 병변과의 연관성을 밝히기 위한 추가 적인 연구가 필요할 것으로 생각된다. 또한 결과에서 알 수 있듯이 전정신경염으로 진단된 환자 1 명에서도 세가지 검사 모두에서 이상소견을 보일 수 있어 세가지 검사 모두에서 이상소견을 보이는 경우에 대한 임상적 의미를 평가하기에 는 다소 부족하다고 생각된다. 이러한 소견을 명확히 해석하 기 위해서는 검사자의 숙련도나 검사 시 병의 증상 정도에 대한 추가적인 평가를 통해 분석 집단을 재설정하여 보다 많은 수의 환자에 대한 분석을 통해 확인할 필요가 있다고 생각된다.

\section{결 론}

결론적으로 본 연구를 통해 단속운동검사, 시추적검사, 시 운동성 안진검사의 이상소견과 중추성 현훈질환의 병변 위 치와의 연관성은 알 수 없었지만, 단속운동검사와 시운동성 안진검사 각각의 이상소견과, 단속운동검사와 시추적 검사, 시운동성 안진검사 세가지에서 동시에 이상소견이 나타나는 환자의 경우 중추성 질환으로 인한 어지럼증의 가능성이 높 다는 것을 제시하였다. 이는 어지럼증에 대한 기초적인 자료 를 제공할 뿐만 아니라, 어지럼증 진단에 대한 검사 개발에 많은 도움을 제공할 것으로 생각된다.

\section{CONFLICT OF INTEREST}

No potential conflict of interest relevant to this article was reported. 


\section{ORCID}

Yoon Seok Choi, https://orcid.org/0000-0002-0616-7122

Si-Youn Song, https://orcid.org/0000-0001-6642-8841

Yong-Dae Kim, https://orcid.org/0000-0003-0501-966X

Chang Hoon Bae, https://orcid.org/0000-0002-0835-4060

\section{REFERENCES}

1. Cook G, Stark L. The human eye-movement mechanism. Experiments, modeling, and model testing. Arch Ophthalmol 1968;79:428-36.

2. Huh YE, Kim JS. Bedside evaluation of dizzy patients. J Clin Neurol 2013;9:203-13.

3. Seferlis F, Chimona TS, Papadakis CE, Bizakis J, Triaridis $\mathrm{S}$, Skoulakis C. Age related changes in ocular motor testing in healthy subjects. J Vestib Res 2015;25:57-66.

4. Chung WK, Lee WS, Choi MS. Clinical significance of the optokinetic nystagmus abnormality. Korean J OtolaryngolHead Neck Surg 1997;40:331-9. Korean.

5. Kim ES, Lee WS, Chung WK, Kim HN, Kim YM, Whang $\mathrm{BK}$, et al. Age specificity in normative data of visual evoked eye movement in healthy subjects. Korean J Otolaryngol-Head Neck Surg 1993;36:1170-80. Korean.

6. Chung WK, Choi YJ, Lee WS, Lee JJ, Chun HS. Clinical significance of saccade abnormalities. Korean J OtolaryngolHead Neck Surg 2000;43:143-8. Korean.

7. Kim JI. Saccade, smooth pursuit and optokinetic system. J Korean Bal Soc 2003;2:17-25.
8. Termsarasab P, Thammongkolchai T, Rucker JC, Frucht SJ. The diagnostic value of saccades in movement disorder patients: a practical guide and review. J Clin Mov Disord 2015; 2:14.

9. Noda H. Cerebellar control of saccadic eye movements: its neural mechanisms and pathways. Jpn J Physiol 1991;41: 351-68.

10. Takemori S, Cohen B. Visual suppression of vestibular nystagmus in rhesus monkeys. Brain Res 1974;72:203-12.

11. Becker W. The control of eye movements in the saccadic system. Bibl Ophthalmol 1972;82:233-43.

12. Bae $\mathrm{CH}$. Differential diagnosis of peripheral vertigo. Yeungnam Univ J Med 2014;31:1-8. Korean.

13. Lee H. Smooth pursuit and optokinetic system. J Korean Bal Soc 2004;3:281-8. Korean.

14. Bogousslavsky J, Regli F. Pursuit gaze defects in acute and chronic unilateral parieto-occipital lesions. Eur Neurol 1986; 25:10-8.

15. Szirmai A, Keller B. Electronystagmographic analysis of caloric test parameters in vestibular disorders. Eur Arch Otorhinolaryngol 2013;270:87-91.

16. Zee DS, Yamazaki A, Butler PH, Gücer G. Effects of ablation of flocculus and paraflocculus of eye movements in primate. J Neurophysiol 1981;46:878-99.

17. Knapp CM, Proudlock FA, Gottlob I. OKN asymmetry in human subjects: a literature review. Strabismus 2013;21:3749.

18. Magnusson M, Pyykkö I. Velocity and asymmetry of optokinetic nystagmus in the evaluation of vestibular lesions. Acta Otolaryngol 1986;102:65-74.

19. Takemori S, Cohen B. Loss of visual suppression of vestibular nystagmus after flocculus lesions. Brain Res 1974;72:213-24. 